Ensino, Saúde e Ambiente-V6 (1), pp. 35-60, abr. 2013

\title{
A SAÚDE E O AMBIENTE NOS LIVROS DIDÁTICOS: VIESES NO ENSINO DE CIÊNCIAS
}

\section{THE ENVIROMENT AND HEALTH THEMES IN DIDATIC}

\author{
Lucile Daniel Moreira' ${ }^{1}$, Maylta Brandão dos Anjos², Giselle Rôças², Sheila \\ Pressentin Cardoso ${ }^{2}$ \\ 1. Bolsista PIBIC IFRJ/CNPq, Licenciando do Curso de Química, Instituto Federal de Educação, Ciência \\ e Tecnologia do Rio de Janeiro, Campus Nilópolis, RJ. \\ 2. Docentes do PROPEC, Instituto Federal de Educação, Ciência e Tecnologia do Rio de Janeiro, Campus \\ Nilópolis, RJ. giselle.rocas@ifrj.edu.br
}

\begin{abstract}
RESUMO
O livro didático atua como um dos principais meios de propagação de ideologias na escola, possibilitando discussões e debates sobre diferentes temáticas. Permite a construção de um diálogo entre o tema central e secundários que se imbricam à discussão ou ao tema. Este recurso didático permite um trabalho com valores e representação do fazer cotidiano, tornando-se ferramenta relevante para o ensino de ciências. Nesse aspecto, a pesquisa teve como objetivo analisar como as temáticas saúde e ambiente - são apresentadas nos diferentes livros do PNLEM de disciplinas que tangenciam o ensino de ciências, doados às escolas públicas de ensino médio de Nilópolis. O principal objetivo foi analisar alguns aspectos do livro didático, cujos resultados serviram de base para a discussão das práticas pedagógicas que orientam a inserção dos temas saúde e ambiente como vieses no ensino de ciências no currículo das escolas públicas de ensino médio.
\end{abstract}

Palavras-chave: ambiente; ensino de ciências; ensino médio; livro didático; saúde

\begin{abstract}
The didactic book promotes the ideologies propagation inside school environment, allowing discussions about the thematic proposed. This resource allows working with the daily basis representation, becoming a significant tool for the science teaching. Therefore, the research aimed to analyze the themes - health and environment - as they are presented in several discipline books of the PNLEM, donated to public schools of basic education of Nilópolis city. The main purpose was to analyze some aspects of didactic books which were used as a base for the analyses related to teachers' performance, as well as, to help with the preparation of didactic material related to the chosen thematic.
\end{abstract}

Keywords: basic education; didactic books; environment; healthy; science teaching 


\section{INTRODUÇÃO}

A orientação dos Guias de Livros Didáticos ${ }^{1}$ assinala que as coleções devem acolher as demandas dos professores, dos alunos e das instituições escolares, auxiliando aos educandos na obtenção de conhecimento, no entendimento das relações sociedade e natureza, proporcionando maior conhecimento e compreensão de mundo que possam conferir maior e melhor qualidade de vida aos sujeitos sociais, bem como maior construção da cidadania e dos valores à vida.

A intenção de trabalhar a análise de livros didáticos tangenciados às temáticas ambiental e da saúde, no ensino formal, reforça a avaliação, que precisa ser executada de forma crítica, acerca das políticas direcionadas ao ensino das questões ambientais e da saúde, dimensões essas constitutivas do ensino de ciências (MARTINS, 2008).

Há que se ponderar uma fala institucional de que o livro didático seria o garantidor da qualidade curricular apresentada aos professores. Essa afirmativa redunda em muitas pesquisas e se constitui num campo polêmico. A opção de trazer para a análise o objeto "livro didático" foi feita em função de ter sido verificado a importância que "os professores atribuem a escolha dos livros didáticos, sobretudo no que se relaciona a adequação ao projeto político-pedagógico das escolas e à realidade da comunidade escolar" (ANDRADE, ANJOS E RÔÇAS, 2009, p. 104).

A importância dada ao livro é também capitaneada pelos órgãos governamentais. Martins (2006, p. 118) deixa claro tal intenção, ao afirmar que

Esta importância é atestada, entre outros fatores, pelo debate em torno da sua função na democratização de saberes socialmente legitimados e relacionados a diferentes campos de conhecimento, pela polêmica acerca do seu papel como estruturador da atividade docente, pelos interesses econômicos em torno da sua produção e comercialização, e pelos investimentos de governos em programas de avaliação.

Tentando alimentar o debate e analisar que importância os livros didáticos assumem no ensino de temas interdisciplinares no ensino de ciências, como ambiente e saúde, recorremos ao cenário de escolas da Baixada Fluminense. Dessa forma, os títulos dos livros aqui analisados foram encaminhados pelas escolas, as quais dispuseram um conjunto de obras para serem avaliadas.

\footnotetext{
${ }^{1}$ Integra tanto o Plano Nacional do Livro Didático (PNLD), quanto o Plano Nacional do Livro do Ensino Médio (PNLEM).
} 
Para analisar se a abordagem dada aos textos dos livros didáticos atendia aos quesitos relativos à inter- e a transdisciplinaridade, assumimos o levantamento histórico realizado por Andrade, Anjos e Rôças (2009), sobre tais conceitos e suas análises em livros. Além disso, levantamos as referências e os elementos considerados essenciais aos temas ambiente e saúde, trabalhando com os 17 livros indicados pelas escolas envolvidas no projeto (Apêndice 1).

Assim, um perfil dos livros e das abordagens ambiental e da saúde contidas nos textos foi realizado, sendo observado que ainda persistem vazios textuais e incongruências em relação aos conceitos de saúde e ambiente e às metodologias empregadas nesse contexto, o que pode implicar em sérios riscos na construção do ensino de ciências voltado ao saber ambiental e ao conhecimento constitutivo da saúde. Nesse caso, o ambiente ainda consta de forma naturalizada e, por algumas vezes, de forma descontextualizada. No campo da saúde resvala-se para o sentido utilitarista e de prevenção à doença, em detrimento do sentido da promoção e das formulações de políticas públicas que tenham saneamento, alimentação e moradia como temas.

Nos norteamos, então, pelas seguintes indagações: Há aplicabilidade dos temas saúde e ambiente nas escolas estaduais da baixada fluminense? Por que identificar a abordagem dessas temáticas nos livros didáticos do ensino formal? Quanto ao primeiro questionamento, Sacramento et al (2010) analisaram em seu estudo, com as mesmas quatro escolas envolvidas aqui, a forma como os temas educação, saúde e ambiente eram trabalhados no currículo das escolas envolvidas, investigando quais as práticas pedagógicas mais comumente utilizadas pelos professores. Este foi o ponto de partida do estudo ora exposto, uma vez que os livros didáticos surgiam freqüentemente nas respostas dos professores. Tal resultado é corroborado por Silva que afirma que "o livro didático, sobretudo a partir da década de 1960, vem sendo utilizado como um mecanismo de (in)formação do professor" (2012, p. 817).

Quanto ao segundo questionamento, assumimos que a argumentação de que o livro didático passou por significativos progressos, necessitou ser verificada à luz das temáticas estudadas e, principalmente, por sabermos que este recurso didático é o principal, e muitas vezes o único, recurso existente em escolas da periferia. Fato esse que aponta a necessidade da análise do tema e a exposição do mesmo, para que novas situações e culturas se formem na dimensão de novas possibilidades que retroalimentem o ensino. 
Assim, partimos para comprovar ou refutar a fala de Freitag e colaboradores ao afirmar que "se com o livro didático o ensino, muitas vezes é frágil, sem ele teríamos uma situação ainda pior" (FREITAG et al., 1997, p. 128). O enlevo de nossa resposta aponta que, em conformidade com Bittencourt (2004), o livro:

não se constitui apenas em acervo de uma área de conhecimento, mas também em livro pedagógico, em que está contida uma concepção de aprendizagem (grifo do autor, p. 298).

Temos claro que o uso dos livros didáticos, necessita de complementaridades que se consubstanciam em leituras de outros materiais didáticos, produzindo, deste modo, resultados consistentes erguidos, em situações que respeitam as conexões existentes entre o cotidiano dos sujeitos escolares e o mundo. Portanto, tê-lo como único instrumento de trabalho, é limitar as infinitas formas de se ensinar e aprender. É reduzir o ensino a um único método ou estratégia que pode se desgastar, caso não seja bem construído durante o processo de ensino,

O livro didático pode operar como um instrumento de controle, legitimado pela tendência posta no contexto político, econômico e social de uma época (MARTINS, SALES E SOUZA, 2009). Seguindo tal linha de raciocínio, as escolas envolvidas nessa pesquisa receberam em outro momento livros paradidáticos, cujos títulos foram indicados pelos próprios professores, para desenvolverem projetos junto aos alunos. A análise desta etapa da pesquisa foi descrita por Moreira, Anjos e Rôças (2011), nessa análise, as autoras ressaltam o fato da participação e indicação dos professores às leituras dos livros que carregam na linguagem simples os pensamentos recheados de formulações e aberturas para a discussão dos temas que se imbricam ao ambiente e a saúde. Assinalam que as escolhas dos livros, nascendo de um processo democrático entre os professores, confere uma nova identidade às leituras, um vigor e um prazer maior de se trabalhar com elas. Denotam a intimidade maior que os professores possuem com a linguagem trabalhada nos livros indicados pelos mesmos. Dessa forma, como mais um recurso utilizado no ensino, facilita a compreensão para fatores concretos e abstratos, que fazem parte do conhecimento e da formulação do saber.

Soares é categórico ao nos alertar que "o livro didático não pode ser compreendido isoladamente, sem que se leve em conta o contexto social" (1996, apud FREITAS \& MARTINS, 2008, p. 12). E é no contexto social que o livro vai ganhar maior expressão, vai se fortalecer nos vários fenômenos expressos em ideias e experimentos. Ao acessar novas redes, os fenômenos vão ganhando maior significados, 
saindo do plano do impossível, alimentando o pensamento concreto e o pensamento abstrato fulcrais no ensino de ciências.

É fundamental ter claro que a pluralidade de materiais didáticos auxilia de forma mais contundente na compreensão dos conteúdos sugeridos pelas instituições educativas. E é se valendo das várias formas e recursos que o ensino se fortalece, que o uso do livro didático toma nova envergadura, se valendo das várias estratégias de compreensão do mundo, de experimentação desse mundo.

Ao considerar os diferentes livros mencionados pelos professores nas escolas trabalhadas, percebemos que tais escolhas assinalam que cada autor indicado estabeleceu as prioridades de assuntos tratando-os dentro dos mais diversos vieses apresentados pelo ensino de ciências. Entretanto, percebe-se também a falta de um diálogo maior que aprofundasse como seria realizado o trabalho intermediado pelas leituras e debates.

Quanto à narrativa dos livros, em alguns deles os saúde e ambiente não se constituíram como temas auxiliares para o maior entendimento e conexão ao tópico que estava sendo abordado nas diferentes unidades/capítulos apresentados no livro. Em outros, a temática elencada para a análise, serviram como complementares ao tópico central, proporcionando aprofundamentos e maior aporte na realidade intermediada pela noção de saúde e ambiente. E por fim, em outros a predominância foi a narrativa linear da temática escolhida com poucos referenciais (apêndice 1). Observou-se ainda nos livros investigados, uma frágil articulação entre os temas saúde e ambiente, saúde e educação, ambiente e educação. As articulações deveriam dar luz e sentido aos temas, entretanto por serem superficiais, enfraqueceram as redes propositivas dos temas e não despertando buscas mais profundas nos alunos.

Avaliamos, também, que em alguns materiais didáticos que possuem um selo indicando que o livro está de acordo com a proposta curricular vigente - nesse caso os PCN - nem sempre se confirmam no interior da obra, sobretudo quando o relacionamos aos temas transversais, e no nosso estudo, saúde e ambiente. Isso denota que, a opção pelo o livro didático precisa ser um momento de extraordinária seriedade e responsabilidade no cotidiano escolar, isso porque se liga como mais um dos componentes didáticos do processo de ensino-aprendizagem.

O livro didático assume função capital para o ensino de ciências por introduzir o leitor não somente na linguagem científica, mas também nos saberes tangenciados na dimensão saúde e ambiente. Essa articulação fortalece o ensino, tanto nas suas questões 
pragmáticas e experimentais quanto nos conceitos políticos e sociais despertadas por uma visão inteligível dos fenômenos naturais, sociais e humanos. O livro, nesse caso pode ser representado como o mediador do humano no seu aporte conceitual, registrado em signos, pensamentos e palavras, Neste contexto, fica claro porque optamos ter, como objeto de estudo, o livro didático. E mais ainda, podemos ressaltar a importância do mesmo como elemento cognitivo e por significar uma possibilidade de ingresso dos alunos à informação e a formação crítica, autônoma e livre.

\section{METODOLOGIA}

O livro didático se constitui no elemento configurador das práticas docentes (SACRAMENTO et al, 2009) nos diferentes níveis de ensino. Tendo como base este pressuposto, buscamos analisar os livros que foram utilizados, durante o ano de 2009, pelos professores das quatro escolas participantes do projeto "As Intersecções dos Temas Saúde e Ambiente no Ensino Formal: Análise das Práticas Docentes e Materiais Didáticos".

Para realizar o presente estudo, procedemos da seguinte maneira: revisão da bibliografia sobre a temática e contato com as escolas selecionadas; identificação e elaboração de uma lista de todos os livros indicados pelos professores; definição dos critérios que foram adotados na análise dos livros; roteiro proposto para cada livro analisado, constando comentários oportunos que permitam identificar a abordagem da questão ambiente e saúde inserida nestes textos, de acordo com os objetivos apresentados.

Assim, analisamos os livros didáticos do PNLEM utilizados em quatro escolas de Ensino Médio do município de Nilópolis, selecionadas através das médias obtidas pelas mesmas no Exame Nacional do Ensino Médio (ENEM) do ano de 2007.

Dessa forma, a pesquisa foi composta pela análise dos 17 livros utilizados pelas escolas (Apêndice 1), nos quais buscamos avaliar se havia ou não as temáticas ambiente e saúde e como se configuravam as abordagens desses temas. Com relação aos PCN, detectamos algumas sugestões alusivas aos temas transversais saúde e ambiente.

Buscamos avaliar como o livro didático sinaliza a problemática ambiente e saúde estabelecida na sociedade e na humanidade, se constituindo como um dos propósitos do ensino de ciências. Assim, para a identificação e análise da forma como os autores dos livros abordam a temática estudada, questionamos como o ensino interdisciplinar e transversal assegura a base do pensamento que orientará as atitudes e 
raciocínios dos alunos do ensino médio nas séries subsequientes, através do que é veiculado nos textos dos livros de diferentes assuntos trabalhados escolares.

Os dezessete títulos distribuídos e analisados eram das seguintes áreas: Códigos e Linguagens, Ciências Humanas, Matemática e Ciências da Natureza. Foram feitas análises individuais dos conteúdos (sinopses), sendo desenvolvida uma ficha de avaliação com dados bibliográficos dos mesmos e uma avaliação sobre como a temática saúde e ambiente havia sido abordada pelos autores de cada título (Apêndice 1).

Assumimos como referencial de análise, das narrativas produzidas nos textos dos livros, Bakhtin (1997), o qual valoriza a fala e a enunciação no que perfaz o sujeito social e no que reafirma o mesmo no conjunto do dizível. $\mathrm{O}$ autor afirma que a natureza social da fala está indissoluvelmente ligada às condições da comunicação, que, por sua vez, estão sempre ligadas às estruturas sociais. E nesse ínterim, a argumentação de Sacramento et al (2009) ganha luz ao falar da relação com o contexto social e das mediações dos temas.

Partindo desse desígnio, observamos que a escolha dos professores pelos títulos nos remete a preferência por gêneros de discursos oficiais e indicados pelo MEC Ministério da Educação e Cultura. Os mesmos poderiam ter indicado qualquer livro, de qualquer editora, mas escolheram os consensuais. Tal fato é rico de uma abordagem interpretativa que remete ao "engessamento" de opiniões e da baixa dialogicidade dos docentes representados na pesquisa.

Martins (2006) ao analisar livros didáticos sob a perspectiva dos estudos do discurso, também elegeu Bakthin como um de seus referenciais. A autora afirma que o autor

(...) confere à linguagem um caráter essencialmente dialógico e nos conclama a compreender uma enunciação como um elo numa cadeia de comunicação, isto é, implicando enunciações que a antecederam e apontando para enunciações que a sucederão (p. 121).

É nesse aporte que Bakthin, trazido para análise dos livros didáticos, embasa uma leitura mais propositiva que nos faz perceber as reentrâncias do enunciado, da intenção que se pretende desse, e das possibilidades que a narrrativa assume na qualificação do ensino. Por meio das formulações enunciativas, Bakhin nos apresenta um universo rico de interpretações que aprofunda o ensino, fortalecendo a visão crítica que se deve ter em torno de campos de saberes que articulam ambiente e saúde. 


\section{RESULTADOS E DISCUSSÃO}

Em nossas análises priorizamos estabelecer um cruzamento do conteúdo elaborado para o livro com os discursos e narrativas realizadas para essa comunicação, de forma a perceber como esses livros tangenciam seu tema central, abordando as temáticas do campo da saúde e ambiente de forma transdisciplinar.

A pesquisa sinaliza que embora, nas diferentes áreas do saber, os textos se constituam como elementos dos discursos científicos e escolares, começam a se aproximar da proposta interdisciplinar ao tentar trazer exemplos do dia-a-dia a serem pensados numa chave de pensamento que traduza os fenômenos científicos e sociais que balizam as questões sociais.

Observamos, ainda, que a interlocução dos leitores com os livros pode acontecer, caso haja apropriação do discurso, de forma direta porque o caráter discursivo explanado nos livros trabalhados pelos professores, busca a participação do leitor com o método de produção do textual que assinalem os conceitos científicos numa apropriação de linguagem comum.

Bakhtin contribui para o entendimento dessa questão na seguinte fala:

A fala só existe, na realidade, na forma concreta dos enunciados de um indivíduo: do sujeito de um discurso-fala. O discurso se molda sempre à forma do enunciado que pertence a um sujeito falante e não pode existir fora dessa forma. Quaisquer que sejam o volume, o conteúdo, a composição, os enunciados sempre possuem, como unidades da comunicação verbal, características estruturais que lhes são comuns e acima de tudo, fronteiras claramente delimitadas. (...) As fronteiras do enunciado compreendido como uma unidade da comunicação verbal é determinada pela alternância de sujeitos falantes ou de interlocutores (Bakhtin, 1997, p. 293).

Percebemos que a linguagem científica, traduzida como um elemento único da argumentação didático/literária não fortaleceu o discurso escolar, nas vertentes de aproximação e apropriação dos conteúdos ali tratados. Para tanto, trazer elementos que dialoguem, na aproximação dos fatores vivenciais, facilita a aceitação e compreensão dos alunos nas diversas áreas do saber. Essa associação entre saberes e temáticas, e aqui em foco o ambiente e a saúde, terão efetiva presença na compreensão científica dos alunos, quando veicularem o conhecimento através das contextualizações possíveis, das intertextualidades discursivas e da produção e apropriação da realidade concreta vivenciada e experimentada pelos sujeitos desses saberes.

Ainda orientados pelas propostas de Bakhtin ao considerar seu pensamento 
acerca do uso da língua nas atividades humanas como elemento essencial no trabalho, salientamos que

Todas as esferas da atividade humana, por mais variadas que sejam, estão sempre relacionadas com a utilização da língua. Não é de surpreender que o caráter e os modos dessa utilização sejam tão variados como as próprias esferas da atividade humana (...). A utilização da língua efetua-se em forma de enunciados (orais e escritos), concretos e únicos, que emanam dos integrantes duma ou doutra esfera da atividade humana. $\mathrm{O}$ enunciado reflete as condições específicas e as finalidades de cada uma dessas esferas (...) cada esfera de utilização da língua elabora seus tipos relativamente estáveis de enunciados (Bakhtin, 1997, p. 290).

Os livros didáticos trabalhados no ensino médio, com alunos da baixada, funcionaram como representações paradigmáticas em que se predominou enunciado emanado, em sua maioria, por um discurso linear e distante das conexões integrantes do pensamento coloquial. A maioria dos livros, nos seus diferentes temas, não expressou a realidade e a necessidade retratada na atividade humana vivenciadas pelos alunos, na qual deveriam estar presente não somente os temas saúde e ambiente, mas a utilização discursiva que institui esses temas nos discursos e práticas discursivas:

Um exemplo de um tema que é apenas um tema seria, por exemplo, "a natureza", o "homem", "a oração subordinada" (um dos temas da sintaxe). Mas o discurso de outrem constitui mais do que o tema do discurso; ele pode entrar no discurso e na sua construção sintática, por assim dizer, "em pessoa", como uma unidade integral da construção (Bakhtin, 2006, p. 147).

A pesquisa ratificou o imperativo da construção do pensamento analítico e crítico para os sujeitos escolares, permitindo que os livros didáticos avoquem o caráter de apenas servir como um dos instrumentos do processo ensino e aprendizagem, tendo em vista que esse pode evocar a criatividade, inventividade e consciência dos alunos, através de um discurso que possui bases no processo científico, mas que não prescinde da articulação, interligação e configuração dos diferentes discursos e temas didáticos. Tal pensamento evoca a seguinte fala:

Um signo não existe apenas como parte de uma realidade; ele também reflete e refrata uma outra. Ele pode distorcer essa realidade, ser-lhe fiel, ou apreendê-la de um ponto de vista específico, etc. Todo signo está sujeito aos critérios de avaliação ideológica (isto é: se é verdadeiro, falso, correto, justificado, bom (Bakhtin, 2006, p. 30). 
Dessa forma, as narrativas produzidas nos textos, devem, na condição de "um que signo não existe apenas como parte de uma realidade", lançar mão aos elementos de contextualização dos temas à realidade circundante. Esses elementos reforçam o pensamento de que o conteúdo temático deve cooperar, de maneira sólida e expressiva, para a escolha dos livros a serem trabalhados no ensino médio, sobretudo numa região que possui suas peculiaridades territoriais e suas necessidades evidenciadas nas questões da saúde e do ambiente, como a baixada fluminense. E assim indagar:

Como é o discurso ativamente absorvido pela consciência e qual a influência que ele tem sobre a orientação das palavras que o receptor pronunciará em seguida? Encontramos justamente nas formas do discurso citado um documento objetivo que esclarece esse problema. Esse documento, quando sabemos lê-lo, dá-nos indicações, não sobre os processos subjetivo-psicológicos passageiros e fortuitos que se passam na "alma" do receptor, mas sobre as tendências sociais estáveis características da apreensão ativa do discurso de outrem que se manifestam nas formas da língua. O mecanismo desse processo não se situa na alma individual, mas na sociedade, que escolhe e gramaticaliza - isto é, associa às estruturas gramaticais da língua - apenas os elementos da apreensão ativa, apreciativa, da enunciação de outrem que são socialmente pertinentes e constantes e que, por conseqüência, têm seu fundamento na existência econômica de uma comunidade lingüística dada (Bakhtin, 2006, p. 149).

Entretanto, de modo geral, observamos que os livros doados foram pouco utilizados, entretanto surtiram efeitos ao grupo participante devido "o discurso veiculado absorvido pela consciência orientar as palavras que o receptor pronunciará" no campo de saber, quando a ele for solicitado.

Dessa forma, "as tendências sociais da apreensão ativa do discurso de outrem que se manifestam nas formas da língua, mostraram que esse processo não se situa na alma individual, mas na sociedade, que escolhe os elementos da apreensão ativa, apreciativa, da enunciação de outrem". A apropriação de um discurso distante ao seu, não levou os alunos a refletirem e a construírem o seu conhecimento de forma crítica conceitual, sobretudo quando se referia a possibilidade do discurso interdisciplinar.

Por fim, ficou claro que os livros analisados possuem plano comunicacional direcionado a alunos do ensino médio, entretanto os signos apropriados por esses tratam do "discurso do outrem". Contudo, o discurso e estilo posto nos conceitos e conteúdos dos livros didáticos não refletem apenas a fala dos autores, mas a obediência destes aos 
ditames do pensamento oficial e ao discurso consensual. A este respeito Bakhtin defende que:

Cada esfera conhece seus Gêneros, apropriados à sua especificidade, aos quais correspondem determinados estilos. Uma dada função (científica, técnica, ideológica, oficial, cotidiana) (...) Sabe-se que os gêneros vão sofrendo modificações em consequência do momento histórico em que estão inseridos. Cada situação social dá origem a um gênero com suas características peculiares. Levando-se em consideração a infinidade de situações (Bakhtin, 1997, p. 284).

A abordagem dos temas saúde e ambiente foram desenvolvidas com outras atividades pedagógicas, em outras perspectivas, como reprodução de vídeos educativos sobre o tema; visitas e desenvolvimento de projetos envolvendo a comunidade escolar; participação de ciclos de palestras e oficina no IFRJ; produção de slides; concursos de histórias de quadrinhos; produção de documentários e jogos didáticos, entre outros. Buscamos desta forma, ao longo de três anos de projetos, permitir que alunos, professores e gestores percebessem que há outras formas e recursos didáticos para o trabalho com temas transversais, particularmente, saúde e ambiente.

Esses projetos incluem atividades como entrevistas sobre hábitos da comunidade em relação as condições de vida. Observamos que alguns professores que trabalharam com os livros não exploram os textos temáticos na sua máxima potência escolar. Isso nos indica que não é suficiente termos novos modelos curriculares e livros didáticos inovadores, se os professores não incorporarem novos propósitos para a educação do ensino de ciências.

Identificamos que os diferentes temas poderiam estabelecer maior relação contextual com as questões da saúde e do ambiente, tendo em vista que os mesmos se constituem como temas sociais que devem ser apropriados nas diferentes áreas do saber e pelos professores das mais diversas disciplinas.

As contextualizações mais freqüentes apareceram nos textos dos livros dedicados as ciências biológicas. Este fato nos remete a Mortimer (1998), quando assinala que se reforça, nos mesmos, o discurso de autoridade próprio do discurso científico que se coloca como único e verdadeiro - elementos esses configurados na prática escolar apresentadas pelos professores sujeitos dessa pesquisa.

Nesse sentido, para Mortimer (1998), é salutar perceber que enquanto na linguagem comum predominam narrativas que relatam seqüências lineares de eventos, a 
linguagem científica congela os processos, transformando-os em grupos nominais que são então ligados por verbos que exprimem relações entre esses processos. Este fato ficou bem aparente nos trabalhos com os livros didáticos nas quatro escolas de Nilópolis.

Entendemos, corroborados nos estudos deste autor, que a linguagem científica é, portanto, predominantemente estrutural enquanto que a linguagem cotidiana é linear. Esta linearidade compromete o entendimento da complexidade que há nos fenômenos próprios das temáticas investigadas nos livros constantes da pesquisa. Entretanto, na linguagem científica, o agente normalmente está ausente, o que pode ter ocasionado certo distanciamento entre os textos e as atividades desenvolvidas nas escolas, que ocasionou a descontextualização dos textos na linguagem cotidiana.

\section{CONSIDERAÇÕES FINAIS}

Pôde-se perceber com a presente pesquisa, que as citações sobre saúde e ambiente nos livros são poucos presentes e, assim, foram realizados poucos trabalhados, principalmente nas práticas de ensino, haja vista a falta de relação apresentada entre os aspectos textuais localizados no âmbito interdisciplinar e os aspectos das práticas sociais nas quais os textos analisados são produzidos e recebidos. Consideramos que a escolha por utilizar um determinado livro e não outro explicitaram, portanto, escolhas pedagógicas específicas e modos de representar as disciplinas, não levando em conta os temas saúde e ambiente. Bourdieu afirma que um livro não chega jamais a um leitor sem marcas. Ele é marcado em relação ao sistema de classificações implícitos (...) quando o livro chega a um leitor, está predisposto a receber marcas que são históricas (apud Cassab e Martins, 2008, p. 18).

$\mathrm{Na}$ análise intertextual, a opção por inserção de trechos retirados de textos revela que o processo de recontextualização discursiva e o direcionamento dado ao texto aconteceram de forma frágil, prejudicando a relação existente com as práticas sociais. A maioria dos livros analisados ainda encontra-se em desacordo com necessidades de divulgação sobre os principais problemas relativos ao ambiente e à saúde, mas ainda assim se destacam pela melhora dos conteúdos informativos e elucidativos dos temas em questão.

Como o acreditado, a maior parte dos livros analisados imprime uma abordagem parcial da questão ambiental, ou seja, seguem correntes de Educação Ambiental que visam apenas sustentar e replicar o padrão de consumo presente, por via do 
contingencial discurso da reciclagem. Isto fica evidente quando descrevem limites ambientais que estão ligados aos interesses econômicos, as quais remetem quase a visão antropocêntrica, o que não acorda com a visão contemporânea que amplifica o pensamento social, ambiental e da saúde, repercutindo numa melhor qualidade de vida. Essa característica dos livros está impressa no pensamento e nas ações dos professores sobre as temáticas abordadas, o que está em acordo com Cassab e Martins ao afirmarem que a escolha de títulos didáticos reflete, ainda que parcialmente o discurso desse sujeito, uma vez que

Por meio de uma investigação acerca dos principais critérios para escolha do livro a ser adotado, exploramos como diferentes formações imaginárias perpassam e são constitutivas dos discursos docentes. Ao formularem estes critérios, nossos professores posicionam-se como sujeitos sociais, estabelecendo relações entre diferentes discursos. Em nossas análises exploramos as condições sociais de produção dos discursos dos professores acerca dos critérios para escolha do livro, discutimos como os professores constroem significações e como estas são perpassadas por diversas formações imaginárias (Cassab e Martins, 2008, p. 6).

A análise de como são trabalhados os temas saúde e ambiente nos textos indicativos dos livros, nos mostra as lacunas e incongruências em relação aos conceitos de saúde e ambiente, o que pode comprometer a construção do pensamento dessas temáticas pelos leitores escolares.

A pesquisa ratificou o imperativo da construção do pensamento analítico e critico para os sujeitos escolares, fazendo que os livros didáticos avoquem o caráter de apenas servir como um dos instrumentos do processo ensino e aprendizagem, tendo em vista que esse pode evocar a criatividade, inventividade e consciência dos alunos, através de um discurso que possui bases no processo científico, mas que não prescinde da articulação, interligação e configuração dos diferentes discursos e temas didáticos (Braga e Mortimer, 2003). Dessa forma, deve lançar mão aos elementos de contextualização dos temas à realidade circundante. Esses elementos reforçam o pensamento de que o conteúdo temático deve cooperar, de maneira sólida e expressiva, para a escolha dos livros a serem trabalhados no ensino médio, sobretudo numa região que possui suas peculiaridades territoriais e suas necessidades evidenciadas nas questões da saúde e do ambiente, como a baixada fluminense.

Portanto, ensinar apenas conceitos descontextualizados e distantes da realidade 
dos alunos já demonstrou ser contra-producente. Os alunos necessitam ser educados a refletir livremente, criticamente e criativamente, para ser raiz de sujeitos melhores e ao mesmo tempo decisivos.

Ao terminar este artigo, cabe-nos a última observação de que a utilização de livros didáticos pode enfatizar as potencialidades criativas consubstanciados nos novos paradigmas interdisciplinares, interativos de enunciação própria e discursos inteligíveis.

\section{AGRADECIMENTOS}

Agradecemos as diretoras, coordenadoras pedagógicas, professores e alunos que participaram desse projeto. Agradecemos também a FAPERJ que nos concedeu apoio financeiro para a condução do estudo e doação dos livros paradidáticos. Pelas bolsas de PIBIC agradecemos ao CNPq e a FAPERJ.

\section{REFERENCIAS}

ANDRADE, T. J. S.; DOS ANJOS, M. B.; RÔÇAS, G. (2009). A árvore na poesia de Drummond: a construção de livro paradidático para a Educação Ambiental. Ciências \& Cognição; Vol 14 (3): 103-113. Disponível em: http://www.cienciasecognicao.org. Acessado em 04 de dezembro de 2012.

BAKHTIN, M. (1997). Estética da criação verbal. Os gêneros do discurso. São Paulo: Martins Fontes.

BAKHTIN, M. (2006). Marxismo e Filosofia da Linguagem. São Paulo:Hucitec.

BITTENCOURT, Ci. M. F. (2004). Ensino de história: fundamentos e métodos. São Paulo, Cortez.

BRAGA, S.; MORTIMER, E. F. (2003). Os gêneros de discurso do texto de biologia dos livros didáticos de ciências. Revista brasileira de Pesquisa em Educação em Ciências, v.3, n.3, set/dez.

BRASIL. (1998). Secretaria de Educação Fundamental. Parâmetros Curriculares Nacionais: apresentação dos temas transversais. V. 8, Brasília, DF.

CASSAB, M.; MARTINS, I. (2008) Significações de professores de ciências a respeito do livro didático. Ensaio. Vol. 10, 1, p. 1-24. Disponível em: http://www.portal.fae.ufmg.br/seer/index.php/ensaio/article/view/144/193 Acessado em 18 de janeiro de 2011.

FREITAG, B.; COSTA, W. F.; MOTTA, V. (1997). O livro didático em questão. São Paulo: Cortez, 1997. 
MARTINS, E. F.; SALES, N. A. O.; SOUZA, C. A. (2009). Estado, o mercado editorial e o professor no processo de seleção dos livros didáticos Est. Aval. Educ., São Paulo, v. 20, n. 42, p. 11-26, jan./abr. Disponível em: http://www.fcc.org.br/pesquisa/publicacoes/eae/arquivos/1464/1464.pdf Acessado em 10 de fevereiro de 2013.

MARTINS, I. (2006). Analisando livros didáticos na perspectiva dos Estudos do Discurso: compartilhando reflexões e sugerindo uma agenda para a pesquisa. Pro$\begin{array}{lllllll}\text { Posições, } & \text { v. } & 17, & \text { n. } & 1 & \text { (49). } & \text { Disponível em }\end{array}$ www.proposicoes.fe.unicamp.br/.../textos/49_dossie_martinsi.pdf Acessado em: 15 de dezembro de 2011

MOREIRA, L. D.; DOS ANJOS, M. B.; RÔÇAS, G. (2011) As intersecções dos temas saúde e ambiente no ensino formal análise das práticas docentes no uso dos livros paradidáticos. Submetido em 2011.

MORTIMER, E. F. (1998). Sobre chamas e cristais: a linguagem cotidiana, a linguagem científica e o ensino de ciências. IN CHASSOT \& OLIVEIRA (org). Ciência, ética e cultura na educação. São Leopoldo, RS: Editora Unisinos, 1998.

SACRAMENTO, P.; RODRIGUES, F.; ARAÚJO, F.; DOS ANJOS, M. B.; RÔÇAS, G. (2010). Intersecções entre saúde e ambiente em escolas estaduais da baixada fluminense: uma análise inicial das práticas docentes. REMPEC - Ensino, Saúde e $\begin{array}{llllll}\text { Ambiente, } & \text { v.3 } & \mathrm{n} & 2 & \text { p.61-72. } & \text { Disponível em: }\end{array}$ http://www.unipli.com.br/mestrado/artigos/31082010/texto6patriciasacramento.pdf

Acessado em 12 de setembro de 2012.

SILVA, M. A. (2012). A Fetichização do Livro Didático no Brasil. Educ. Real., Porto Alegre, v. 37, n. 3, p. 803-821, set./dez. Disponível em: http://seer.ufrgs.br/educacaoerealidade/article/viewFile/20373/23410. Acessado em 12 de fevereiro de 2013. 
Ensino, Saúde e Ambiente-V6 (1), pp. 35-60,abr. 2013

APÊNDICE 1 - DADOS DOS LIVROS DIDÁTICOS ANALISADOS.

\begin{tabular}{|c|c|c|c|}
\hline Título & Autor/Ano/Volume & Área & Sinopse \\
\hline $\begin{array}{l}\text { 1. Língua, literatura e } \\
\text { produção de texto }\end{array}$ & $\begin{array}{c}\text { Maria Luiza Aburre; } \\
\text { Marcela Regina Nogueira } \\
\text { e Tatiana Fadel. } 2006 . \\
\text { Vol. Único. Moderna }\end{array}$ & $\mathrm{CL}$ & $\begin{array}{l}\text { Segundo os resumos apresentados para a divulgação do livro, o mesmo se distingue pela seleção de seus textos, } \\
\text { direcionados aos alunos do ensino médio, desenvolvendo o interesse pela leitura. As sugestões de produção de textuais } \\
\text { propõem por em destaque as atividades relativas a técnicas para escrever, buscam propiciar o desenvolvimento da } \\
\text { competência textual. Entretanto, não abre o suficiente para que os alunos coloquem em foco os temas transversais, no } \\
\text { caso desse trabalho, saúde e ambiente. Está, substancialmente, relevante ao incentivo ao ensino da língua. Os conteúdos } \\
\text { são bem sistematizados, sob a visão do ensino da gramática tradicional. Todavia, a lacuna reside em não levar em conta } \\
\text { as novas variações da língua, fato este que auxiliaria o aluno a compreender melhor sua fala, contextualizá-la, se } \\
\text { apropriando da mesma. Um dos pontos interessantes é a variação lingüística trabalhada de forma a contribuir para a } \\
\text { constituição de um leitor clarificado quanto aos convencionalismos que geram exclusão social e preconceitos, decorrente } \\
\text { da linguagem falada pelos sujeitos que não tiveram acesso à língua oficial. A informação literária é seqüenciada } \\
\text { obedecendo à temporalidade correta. Nos dos doze capítulos dedicados à Literatura, os assuntos são trabalhados em } \\
\text { conjunto com as imagens. As atividades realizadas seguiram a proposta orientada pelo Manual do Professor. Destarte, a } \\
\text { abordagem literária não é inovadora, e deixa uma lacuna no campo interdisciplinar ao não trabalhar com temas } \\
\text { contingenciais e importantes no contexto da saúde e do ambiente para alcançar os objetivos de um aluno autônomo e } \\
\text { ciente desses assuntos. }\end{array}$ \\
\hline 2. Português: projetos & $\begin{array}{l}\text { Carlos Emílio Faraco e } \\
\text { Francisco Marto de } \\
\text { Moura. 2009. Vol. Único. } \\
\text { Ática }\end{array}$ & CL & $\begin{array}{l}\text { O livro proporciona textos literários e não-literários de qualidade, que são desenvolvidos nas atividades de leitura, } \\
\text { produção e exploração de conteúdos lingüísticos e literários. Há uma escolha de autores que apresenta um conjunto } \\
\text { múltiplo e moderno, não obstante os poemas e textos em prosa são poucos aproveitados para análise e interpretação de } \\
\text { suas estratégias de construção. A articulação entre literatura e outras artes presta bons tempos de intertextualidade. } \\
\text { Entretanto, como no livro anterior, poucos textos são dedicados para a construção de um pensamento ambiental } \\
\text { tangenciado à saúde e aos textos literários. Dessa forma, apesar da tentativa de trazer textos literariamente consagrados, } \\
\text { falta à totalidade do trabalho nas questões que atravesse a abordagem interdisciplinar. Tal fato deveria acontecer com } \\
\text { mais acuidade, sobretudo por considerar que o tratamento conferido aos motes lingüísticos enfoca os usos essenciais da } \\
\text { língua nas distintas circunstâncias de interação social, sem se restringir ao simples reconhecimento da nomenclatura ou } \\
\text { da categorização desses subsídios. Por fim, é oferecido para consulta um apêndice gramatical, que organiza alguns }\end{array}$ \\
\hline
\end{tabular}


Ensino, Saúde e Ambiente -V6 (1), pp. 35-60, abr. 2013

pontos de gramática necessária a sua maior compreensão. Esse apêndice é precário, porque não confere espaço para discussão ou crítica aos conteúdos ali focalizados que são apresentados de forma descontextualizada, sem articulação com a orbe mais ampla da textualidade e com as conexões entre saúde e ambiente que essa possa ter.

A abordagem que se dá obedece, cronologicamente, os fatos e acontecimentos que configuraram o pensamento literário. Apresenta os dados históricos e aspectos estéticos e literários que prevaleceram nos diferentes tempos históricos. Os assuntos são voltados para os estilos de época. Oferecem de modo vivo e sólido, autores capitais para o pensamento da literatura. Os textos são dialogais, apresentando manifestações culturais outras na tentativa de uma interlocução no campo das culturas literárias, fazendo ver a relação entre eles e a constituição de uma memória cultural dinâmica, desenvolvida historicamente e ainda em andamento. Os três volumes da coleção apresentam bons roteiros que sugerem obras literárias e filmes, estimulando 0 aluno a ampliar seu universo cultural. Possui boa articulação entre as atividades de leitura, produção textual e literatura, privilegiando-se a teoria dos gêneros textuais e função comunicativa como princípio organizador do trabalho de leitura e produção. 0 texto é sempre concebido como processo construído em

William Roberto Cereja e

3. Português Thereza Anália Cochar Linguagens Magalhães. 2005. Vol. Único. Saraiva
Amaral; Mauro Ferreira,

Severino Antônio e
CL situação de interação, já que todas as atividades pressupõem a presença de um interlocutor, em uma abordagem perfeitamente condizente com os princípios sociointeracionistas de linguagem que embasam a obra. 0 detalhamento dos diferentes modos de organização discursiva torna possível a exploração da estrutura dos textos nas atividades de leitura, produção e reflexão sobre o funcionamento da língua. 0 livro busca posicionar de modo crítico e atuante os leitores em diferentes práticas sociais, entretanto não "amarra" esse posicionamento com as questões de saúde e de ambiente. As competências lingüísticas são desenvol vidas a partir da problematização dos conteúdos e das situações de aprendizagem oferecidas. Os exercícios repetitivos e mecânicos são evitados, dando destaque a reflexão e a sensibilidade dos leitores. Porém, não evidencia os aspectos conexos e correlatos aos temas trabalhados como forma de oferecer aos leitores maiores perspectivas de associações. Em função da proposta teórico-metodológica assumida para 0 tratamento dos conhecimentos lingüísticos, causa estranhamento o uso do texto como pretexto para a abordagem predominantemente prescritiva e classificatória de questões fonológicas, morfológicas e sintáticas, o que contraria a adequada orientaçãa sociointeracionista desenvolvida na maior parte da obra. Por fim, trabalha a intertextualidade, não indo além do protocolo escolar.

CL Na abordagem do ensino de literatura e no tratamento dado ao texto o livro é sólido e cumpre 0 objetivo de ser elemento articulador das atividades literárias, lingüísticas e de leitura. Apresenta um enfoque adequado, não obstante conservador. 
Ricardo Leite. 2005. Vol.

Único. FTD
Ilustra a trajetória da literatura brasileira desde as suas raízes até a atualidade, num amplo panorama que articula o fundo sócio-histórico, os traços estilísticos, os principais autores e obras de cada época, vinculando-os também, constantemente, à literatura portuguesa. Contemplam-se, além disso, as literaturas africanas de expressão portuguesa, 0 que é insólito nos livros didáticos. 0 trabalho de leitura e releitura dos textos revela o deliberado propósito de que essas atividades capacitem 0 aluno para a atenta consideração dos subsídios essenciais da expressão literária. 0 livro carece de maior aprofundamento acerca das questões da saúde e ambiente voltadas ao aspecto literário. Observamos que os conteúdos lingǘsticos são propostos a partir de um ponto de vista tradicional, não obstante a obra contraponha, em alguns momentos, regras normativas a regras de uso efetivo da língua, segundo orientações atualizadas de pesquisa linguística. As atividades propostas, com base na análise de textos de gêneros variados, levam 0 aluno a pensar de forma criativa os conhecimentos linguísticos na leitura e na produção de textos, considerando suas extensões semânticodiscursivas e morfossintáticas. Falta na obra uma proposta específica para a modalidade oral, o que fica evidente quando se fala da intertextualidade que cabe ao texto provocar.

Os conteúdos apresentados são de Álgebra, Geometria, análise de funções elementares e noções de Matemática Financeira, de Estatística e de Probabilidade. A seleção de tópicos, e ordenada por capítulos, obedece àqueles tradicionalmente abordados no ensino médio e encerra-se com uma Introdução ao Cálculo, tema geralmente observado no ensino superior. A linguagem é muito específica, não abrindo para a conexão com temas correlatos a cotidianeidade dos leitores alunos. Os capítulos no seu inicio possuem situação-problema, o que destacamos como ponto importante coadunando-se ao objetivo do exercício interdisciplinar. Apesar de iniciar com situação-problema, não aprofunda no José Ruy Giovanni; José

5. Matemática completa Roberto Bonjorno. 2005. MCN Vol. Único. FTD objetivo de instigar nos sujeitos leitores sua ativa participação. A sistematização teórica aplica 0 modelo clássico: definições exemplificadas, afirmações com ou sem validação e ilustrações de procedimentos, regras e aplicações. 0 capítulo é finalizado com seções de exercícios de fixação e de recapitulação, muitos deles envolvendo situações do cotidiano. Os recursos didáticos disponibilizados na coleção constituem-se apenas de exercícios e textos para leitura. 0 cuidado com a contextualização, a interdisciplinaridade são minoradas em função dos conteúdos mais diretos. Fato esse que observamos quanto a utilização da máquina de calcular que aparece em considerável parte da obra. Os textos de leitura contemplam diversos assuntos, entretanto não dá destaque aos assuntos sugeridos nos PCN, o destaque é dado aos guias sobre profissões. A linguagem científica inclui a terminologia técnica. Assim, é precisa e consoante com os discursos produzidos para alunos do ensino médio. Possui muitos gráficos, tabelas e demais recursos gráficos, 
Ensino, Saúde e Ambiente -V6 (1), pp. 35-60, abr. 2013

\begin{tabular}{|c|c|c|c|}
\hline & & & $\begin{array}{l}\text { constituindo representações perfeitamente utilizadas. Os textos e a linguagem não apresentam grandes barreiras, } \\
\text { possibilitando, dessa forma, o estudo individualizado possui os capítulos divididos em seções finalizadas com exercícios } \\
\text { de fixação. Em seu início há uma abreviada apresentação, seguida do sumário, capítulos divididos em seções, capítulo } \\
\text { final com respostas dos exercícios, lista de endereços eletrônicos e livros para leitura e pesquisa, lista de siglas utilizadas } \\
\text { na obra e bibliografia. Encontram-se reproduzidas questões do ENEM, com respostas. O Livro do Professor transcreve } \\
\text { as respostas dos exercícios, mas sem indicar suas resoluções. Os capítulos temáticos ganham tratamento unificado. No } \\
\text { final do capítulo, encontra-se uma seção extra, intitulada "recordando" com exercícios de revisão, em sua maioria } \\
\text { coletados de vestibulares. Caixas de textos para leitura acham-se distribuídas ao longo da obra e versam sobre vários } \\
\text { temas interdisciplinares, tais como origem étnica, vôlei de praia, potássio e acidentes de trabalho. O que nos aponta uma } \\
\text { tentativa maior de correlacionar os assuntos trabalhados às situações acontecidas na vida dos leitores. Esse fato redunda } \\
\text { nos novos apelos educacionais que estabelece como uma das diretrizes a associação dos conteídos. Observamos, ainda, } \\
\text { que outros textos assinalados no livro dizem respeito a profissões ou à História da Matemática. } 0 \text { Livro do Professor } \\
\text { difere do Livro do Aluno pelo acréscimo de um apêndice contendo um esboço dos princípios teérico-metodológicos que } \\
\text { nortearam a elaboração da obra. } 0 \text { que parece conferir ao professor maior intimidade e domínio do assunto. No apêndice } \\
\text { de cada volume, descrevem-se os objetivos dos capítulos e sugestões de atividades extras o que provoca a existência da } \\
\text { intertextualidade }\end{array}$ \\
\hline 6. Aula por aula & $\begin{array}{l}\text { Claúdio Xavier da Silva e } \\
\text { Benigno Barreto Filho. } \\
\text { 2005. Vol. Único. FTD }\end{array}$ & $\mathrm{ICN}$ & $\begin{array}{l}\text { Os conteúdos são os normalmente estudados no ensino médio. Cada tópico é iniciado por textos que relatam fatos } \\
\text { históricos ou fazem considerações sobre a sua origem e importância. Alguns temas, no entanto, apenas são motivados } \\
\text { mediante alguma situação-problema, fazendo com que parte da contextualização de certos conceitos aconteça bem após } \\
\text { a sua introdução. Contem um número plausível de aplicações a outras áreas da ciência, como Física, Economia e } \\
\text { Biologia. Dentre elas, algumas são sugeridas como problemas e analisadas nas seções de textos. De modo geral, são de } \\
\text { amplo interesse, dado o conteúdo científico e histórico. } 0 \text { Manual do Professor traz uma descrição geral, contendo a } \\
\text { metodologia afeita a cada um dos capítulos. Os objetivos de um tema tratado em um dado volume aparecem na mesma } \\
\text { ordem sequiencial mostrada no sumário. Seguindo o modelo proposto, encontra-se a descrição da metodologia } \\
\text { apropriada a cada um dos temas abordados. Cada capítulo é iniciado com uma seçãa "A história conta", que traz fatos } \\
\text { históricos pautados ao tema abordado. Em seguida, os conceitos a serem estudados são motivados por algum problema } \\
\text { e, então, definidos e ilustrados com exemplos. Na seção "Participe das resolucçoes", são apresentados e resolvidos alguns }\end{array}$ \\
\hline
\end{tabular}


Ensino, Saúde e Ambiente -V6 (1), pp. 35-60, abr. 2013

exercícios sobre 0 assunto discutido e, dentro de "Elabore as resoluções", são propostos exercícios aos alunos. 0 que provoca a existência de uma interação leitor e autor, através, também de algumas atividades que aplicam os temas estudados às mais diversas situações que são sugeridas nas seções "Desenvolva a criatividade" e "Desenvolva competências e amplie o conhecimento". Na subdivisão "saiba um pouco mais", são abordados argumentos de interesse geral ou acontecimentos científicos curiosos. No final de cada capítulo, é feito um resumo dos assuntos estudados em "Avalie seu conhecimento" e são propostos mais exercícios em "Atividades complementares", que inclui também problemas oriundos de vestibulares. Assim, abre para que a intertextualidade seja explorada no sentido de melhor realizar associações e analogias com assuntos tangenciados aos textos. Observamos a tentativa dos autores em fornecer um elenco maior de informações, para além dos conteúdos, para que os alunos exercitem a sua criatividade e criem um discurso próprio, tendo com base um repertório informativo.

A abordagem busca construir um conhecimento geográfico crítico, indicando o estudo dos aspectos sociais, econômicos, políticos e culturais de forma integrada com os aspectos ambientais, entretanto não lança luz sobre 0 aspecto da saúde. Assim, possui esta lacuna, que poderia fortalecer aos textos ali trabalhados. Os assuntos tratados requerem um maior aprofundamento teórico-conceitual, que propicie a compreensão dos processos e estruturas fundamentais da produção do espaço e na apropriação dos mesmos. Deparamos, deste modo, com algumas insuficiências conceituais na esfera da

Levon Boligian e

7. Geografia, espaço e Andressa Turcatel Alves vivencia

Boligiani 2005. Vol.

Único. Saraiva abordagem pretendida, sobretudo quando assinalamos a temática ambiente e saúde. A orientação didático-pedagógica possui como proposta a valorização da experiência de vida do leitor - aluno do ensino médio - que é respeitado em sua CH inventividade, liberdade, articulação de idéias e competência 0 discurso promovido pelo livro é de mediação, desafio e questionamento. Este fato nos remete a uma análise calcada nas compreensões dos signos lingüísticas que são carregados ao relatar os diferentes acontecimentos históricos. Neste contexto, leva 0 professor a sistematizar 0 conhecimento, verificando as distintas propostas que estimulam os processos cognitivos básicos. Os textos buscam trabalhar a intertextualidade instigando o leitor, não somente a compreensão dos conteúdos históricos, mas a construir um discurso da sua realidade intermediado aos fatos históricos. Por um lado, cumpre o objetivo de integrar a história a realidade social, por outro, é lacunar quando não trata da questão por inteiro. E, no momento presente, não tratar dos temas relacionados à boa qualidade de vida conformada pela díade saúde e ambiente é deixar a "bola bater na trave".

\section{Geografia geral e do Ivan Lazzari Mendes e Brasil James 0nnig Tamdjian.}

$\mathrm{CH}$ As dinâmicas e os processos físicos e socioeconômicos constituintes do espaço geográfico são estudados, no livro, com base em três eixos metodológicos, aplicados aos conteúdos: tempo, conceito e cogniç̧ão. 0 conceito trabalhado em 

relações sociedade-natureza. Neste ponto, avança para um discurso que busca a contextualização do tema no seu aporte social, estabelecendo no campo da crítica, veiculações conceituais. Remete a um discurso narrativo dos acontecimentos na concretude de suas realizações. Os conceitos buscam favorecer a compreensão integrada da realidade, mas apresenta arestas nessa tentativa ao não trazer textos instigantes que propiciem aos questionamentos e ao trabalho com os temas saúde e ambiente. Quanto aos principais aspectos físicos e sociais trabalhados pela geografia, nem todos os temas se apresentem explicitados. Todavia, os conteúdos são apresentados em textos e atividades que buscam contemplar, de modo compreensivo, o estímulo aos processos cognitivos, permitindo uma concepção critica do desenvolvimento e ocupação do uso do espaço. Os elementos de intertextualidade contribuem para a construção de saberes que estão conexos ao ensino da geografia, entretanto, o texto ainda é tímido por não explorar assuntos e vertentes que se voltam à qualidade e formação dos conceitos geográficos ligados à saúde e ao ambiente. Assim, o discurso que se estabelece no livro é linear no campo de conhecimento geográfico.

As questões desenvolvidas no livro parecem ser desafiadoras para os sujeitos leitores. A linguagem e 0 discurso trabalhados fogem ao coloquial e não é totalmente científica. Assim, busca um meio termo que demonstra avanço, para o conhecimento que começa a ser conformado dentro do novo paradigma científico sistêmico e interdisciplinar. Trabalha com 0 conceito de geografia problematizando, sobretudo na questão políica, o tema geográfico. Conseqüentemente, obedece aos quesitos de ser um material didático para que o professor possa cumprir seu lugar em sala de aula. Ao sugerir ações pedagógicas, organiza os conteúdos, fazendo com que o processo de ensino-aprendizagem

Carlos Moreira e José

9. Geografia Eustáquio de Sene. 2005.

Vol. Único. Scipione se torne mais dinâmico e motivador para alunos e professores. Sendo assim, lança mão a um discurso em que 0 aluno se CH sente contemplado. 0 conjunto de conteúdos proposto na obra mostra coerência e preocupação em estabelecer 0 quadro de relações com perspectivas diversas da política, da econômica e do ambiente. No entanto, não faz a ligação desses temas com 0 conceito da saúde. Inferimos, a partir das análises nos livros até aqui trabalhados que a ciência geográfica e histórica, na perspectiva das ciências sociais, nas duas últimas décadas, começa a incorporar 0 discurso ambiental, ato esse que ainda não incorporou o discurso da saúde. 0 que podemos concluir é que corre uma articulação pedagógica em que elementos complexos adicionados pouco a pouco, sobretudo nos resultados advindos do seu uso. A proposta é que se possa começar a trabalhar com 0 livro a partir de qualquer uma das suas unidades. Faz com que cada texto seja autoexplicativo, permitindo a sequiência ou não do assunto. № entanto, apesar dos capítulos apresentarem essa possibilidade 
Ensino, Saúde e Ambiente -V6 (1), pp. 35-60, abr. 2013

pelos seus textos, a atuação do aluno como agente no processo de aprendizagem fica restrita, já que as atividades contidas no livro se concentram principal mente nas questões de memorização em detrimento das questões reflexivas e dialogais.

A coordenação dos conteúdos satisfaz ao encadeamento dos assuntos ali tratados. Obedece a uma ordem cronológica, sem isolamento entre História Geral, do Brasil e da América. Enfatiza a abordagem de eventos acontecidos recentemente. Possui ilustração diversificada e associada aos conteúdos. Há mapas e boxes que apresentam textos complementares e documentos históricos incluídos aos temas transversais pluralidade cultural, Ética e cidadania, Trabalho e consumo e Ciência e tecnologia. Todavia o trabalho com os temas saúde e ambiente são exíguos, o que para

Eduardo A.B. Ojeda, Nicolina Luiza, Petta e

10. Uma abordagem integrada

Luciano Emidio Delfim. Ano 2005. Vol. Único.

Moderna nós se constitui num limite interdisiciplinar que prejudica a construção de uma visão mais ampliada por parte dos leitores acerca dessa questão. 0 texto didático e as atividades parecem estimular habilidades cognitivas. 0 manual do CH professor contém filmografia e extensa bibliografia, além de orientações para o trabalho com os textos complementares e as imagens. Como imperam questões escolhidas de exames vestibulares, não há investimento na produção de textos pelos alunos. 0 que para nós representa uma grande lacuna. Além disso, são poucas as prestezas que geram a averiguação, a reflexão e 0 debate acerca de temas relacionados à sociedade contemporânea nas suas vertentes constitutivas de qualidade de vida. Na abordagem dos conteúdos, não ocorre a incorporação das diferentes renovações historiográfica. Há, também, muitas simplificações explicativas que comprometem a construção dos conceitos históricos fundamentais. As ilustrações são acompanhadas de legendas que não promovem a contextualização adequada das imagens com os fatos históricos e apresenta créditos incompletos, o que compromete 0 texto e a fluidez da narrativa.

A história é apresentada de forma associada, disposta, cronologicamente, desde "As grandes origens" até "Mundo atual". Problematiza a noção histórica e dá valor a variedade de possibilidades interpretativas e ao desempenho dos homens comuns como agentes históricos. Coloca 0 diálogo entre 0 passado e 0 presente de forma linear, 0 que não

11. Nova História crítica

Mário Furley Schmidt. 2005. Vol. Único. Nova Geração favorece a ampliação da discussão. Busca incluir os conteúdos históricos à realidade atual e aos saberes dos alunos, mas CH peca ao não potencializar a discussão. Ao longo do texto e das atividades, dá acuidade ao discurso da interdisciplinaridade, verificando a incorporação da produção historiográfica recente. Por fim, prioriza 0 ensino voltado para a formação do aluno como um cidadão autoconsciente e crítico. № entanto, certas simplificações explicativas, somadas à ausência de discussão de fontes e de indicações bibliográficas no Livro do Aluno, prejudicam, em parte, alguns dos objetivos traçados. Os exerćícios indicados não instigam satisfatoriamente 0 aumento de algumas 
Ensino, Saúde e Ambiente -V6 (1), pp. 35-60, abr. 2013

\begin{tabular}{|c|c|c|c|}
\hline & & & $\begin{array}{l}\text { Dacidades, como a formulação de hipóteses e a produção de textos; também não impulsionam a socialização dos } \\
\text { nos. }\end{array}$ \\
\hline 12. Química e sociedade & $\begin{array}{l}\text { Widson L.P. Santos, } \\
\text { Gerson S. Mól, Roseli T. } \\
\text { Matsunaga, Siland M. F. } \\
\text { Dib, Eliane N. Castro, } \\
\text { Gentil S. Silva, Sandra M. } \\
\text { 0. Santos e Sálvia B. } \\
\text { Farias. 2005. Vol. Único. } \\
\text { Nova Geração }\end{array}$ & $\mathrm{MCN}$ & $\begin{array}{l}0 \text { livro Química e sociedade se distingue por apresentar um modelo curricular que busca adicionar à organização } \\
\text { clássica do conteúdo de química temas como CTS (Ciência, Tecnologia e Sociedade) que são explorados em seus } \\
\text { diversos aspectos sociocientíficos. Entretanto não faz uma relação entre esses temas com os aspectos ambientais e da } \\
\text { saúde. Elementos de intertextualidade são trabalhados no propósito de aproximar os fenômenos próprios da química ao } \\
\text { entendimento dos alunos. Ainda que a tentativa seja de ampliação e apropriação do assunto por parte dos leitores, os } \\
\text { exercícios e textos não flexibiliza num discurso mais próximo e inteligível para os alunos. Sendo assim, denota-se, } \\
\text { também que para uma complementaridade dos assuntos e para maior solidez e noção sistêmica do mesmo, é } \\
\text { imprescindível trabalhar os fenômenos químicos num processo inteligivel da realidade. }\end{array}$ \\
\hline 13. Física & $\begin{array}{c}\text { Antônio Máximo Ribeiro } \\
\text { da Luz e Beatriz } \\
\text { Alvarenga Álvares. } 2005 . \\
\text { Vol. Único. Scipione }\end{array}$ & $\mathrm{MCN}$ & $\begin{array}{l}\text { Apresenta um tratamento conceitual contextualizado, incluso os conhecimentos proporcionados a circunstâncias do } \\
\text { cotidiano. Os conteúdos abordados são os tradicionalmente presentes no ensino de Física do Ensino Médio, sendo } \\
\text { apresentados de maneira abrangente. Há um conjunto extenso de atividades e expedientes para as tarefas do professor, } \\
\text { como leituras, experiências e exerćícios de vários níveis de complexidade. Leis, modelos e teorias físicas recebem } \\
\text { tratamento conceitual adequado, procurando equilibrar o formalismo matemático com uma linguagem clara, objetiva e } \\
\text { atual. Em sua apreensão de oferecer o conhecimento científico de forma contextualizada, emprega com inclusão } \\
\text { elementos de História e Filosofia da Ciência em todos os capítulos, por intermédio de leituras específicas. } 0 \text { que denota } \\
\text { uma tentativa de dialogo interdisciplinar. } 0 \text { livro do professor é um instrumento fundamental para o trabalho } \\
\text { pedagógico, pois apresenta dados relevantes para o incremento dos conteúdos e efetivação de atividades, experimentos e } \\
\text { exercícios. Permite adequação a diferentes contextos escolares, enriquecendo o ensino da Física nas escolas públicas e } \\
\text { atendendo adequadamente às finalidades legais da formação no Ensino Médio. }\end{array}$ \\
\hline 14. Universo da física & $\begin{array}{l}\text { José Luiz Pereira } \\
\text { Sampaio e Caio Sérgio } \\
\text { Vasques Calçada. Ano } \\
\text { 2005. Vol. Único. Saraiva }\end{array}$ & $\mathrm{MCN}$ & $\begin{array}{l}\text { Os conteúdos apresentados abrangem as áreas de conhecimento da Física, sendo abordados de forma clara, objetiva e } \\
\text { estruturados conceitualmente. } 0 \text { livro apresenta os temas na forma tradicionalmente utilizada nos livros de Física do } \\
\text { Ensino Médio, intercalando os conteúdos programáticos com um grande número de exercícios de aplicação e exemplos } \\
\text { resolvidos com as discussões pertinentes. Há textos teóricos nos quais os conceitos capitais são ampliados e outros com } \\
\text { modo mais explicativo que exploram discussões sobre conceitos el ou fatos polêmicos, apresentação de fatos históricos } \\
\text { e/ ou biográficos assim como textos voltados para } 0 \text { aprofundamento de alguns conceitos. Todos esses elementos são }\end{array}$ \\
\hline
\end{tabular}


apresentados de forma equilibrada. A opção metodológica consiste em apresentar os conteúdos clássicos de uma forma sintética, em pequenas doses, com aplicações em situações relacionadas ao cotidiano e discussões sobre aspectos históricos pautados, com distintas ênfases em cada tema. No livro do professor, a narraçãa da composição particular da obra é detalhada e possibilita a sua caracterização. Contudo, os objetivos gerais e específicos são mencionados de modo genérico, sendo que em alguns momentos não há articulação entre esses objetivos e as possibilidades realmente oferecidas pelo livro do aluno

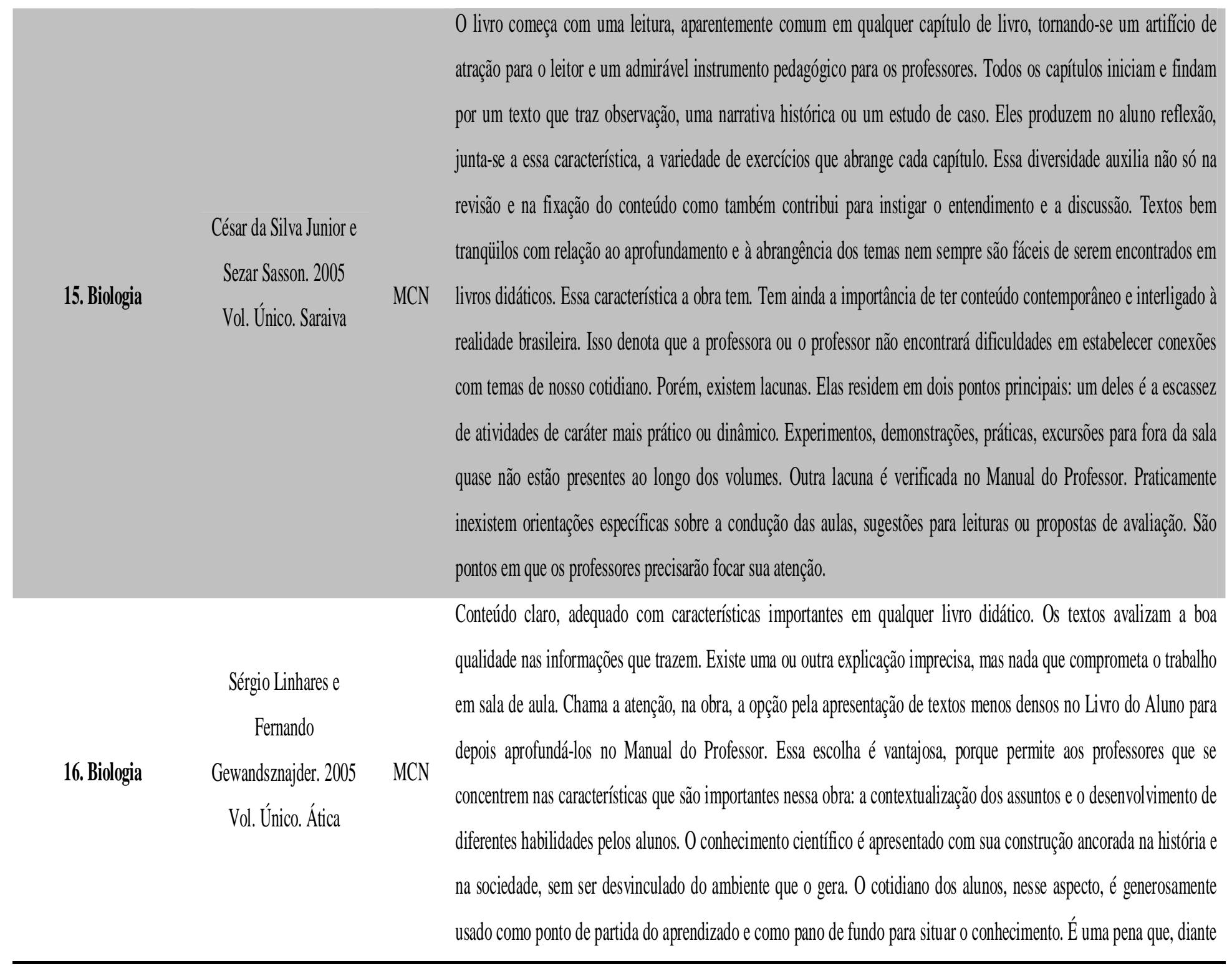


de tantas oportunidades para facilitar 0 aprendizado, haja tão poucos experimentos e atividades práticas sugeridas pela obra. Professora e professor devem complementar essa lacuna. É uma pena também que haja tão poucos exemplos de plantas e animais brasileiros. Um aspecto positivo da obra reside nas oportunidades que ela fornece para 0 desenvolvimento de consciências críticas e cidadãs. Bom exemplo é a discussão sobre a falta de base científica que justifique a existência de raças e etnias superiores ou inferiores. Base sólida os professores também encontram em seu manual. Os textos oferecem várias possibilidades para 0 trabalho em sala de aula e para 0 uso de diferentes recursos pedagógicos. A atualização da professora e do professor é garantida por uma larga oferta de textos adicionais para leitura, que permitem o aprofundamento nos assuntos tratados no Livro do Aluno. Todavia, nem tudo na obra é texto. Há também boas ilustrações e esquemas que colaboram de maneira significativa para 0 aprendizado. 0 texto alerta 0 leitor para 0 fato de que as figuras e os esquemas não estão em proporção e as cores são apenas ilustrativas, mas faz isso somente numa página, $\log 0$ no começo da obra. Serve como aviso: cabe aos professores assumir essa função que seria do livro e esclarecer, eles próprios, aos alunos sobre figuras fora de proporção e sem escala, ou com cores que não correspondem à realidade.

\begin{tabular}{|c|c|c|c|}
\hline \multirow{14}{*}{ 17. Biologia } & \multirow{14}{*}{$\begin{array}{l}\text { Sônia Lopez e Sérgio } \\
\text { Rosso. } 2005 \\
\text { Vol. Único. Saraiva }\end{array}$} & \multirow{14}{*}{ MCN } & Conceitualmente os textos favorecem a compreensão pelo aluno, pois são geralmente claros e bem redigidos. Alguns \\
\hline & & & assuntos que trazem dificuldades para os alunos são trabalhados de modo apropriado e acessível. Contudo, também tem \\
\hline & & & seus lapsos conceituais, que exigirão atenção da professora e do professor. Esses deslizes são mais notáveis nas áreas de \\
\hline & & & genética, evolução e biologia celular e molecular. A metodologia usada pela obra tem suas características, mas, também, \\
\hline & & & tem sua dificuldade. A maneira como a nomenclatura anatômica atual é apresentada, a presença de indicador remissivo, \\
\hline & & & os textos propostos para discussão, que são recursos importantes para a contextualização dos assuntos trabalhados em \\
\hline & & & sala, todos esses são aspectos de caráter prático, com os quais a professora e o professor poderão contar para tornar suas \\
\hline & & & aulas instigantes e de boa qualidade. Para conseguir esse resultado, será preciso um esforço para prover algumas \\
\hline & & & carências, como o uso de termos técnicos em redundância (em alguns capítulos) e a ausência de explicação de alguns \\
\hline & & & termos, ou o papel tímido conferido ao conhecimento prévio dos alunos na abordagem dos assuntos. Com frequiência, a \\
\hline & & & obra faz um bom uso da história das ciências para contextualizar 0 tratamento dos assuntos e mostra uma apreensão com \\
\hline & & & a integraçãa do conhecimento biológico construído pelo aluno. É um infortúnio, contudo, que ela também cometa uma \\
\hline & & & série de equívocos epistemológicos, que precisarão de atenção do professor. Esta é uma obra adequada no que diz \\
\hline & & & respeito à construção da cidadania pelo aluno, com destaque para os textos propostos para discussão, que tratam muitas \\
\hline
\end{tabular}


Ensino, Saúde e Ambiente -V6 (1), pp. 35-60, abr. 2013

vezes das relações entre ciência, tecnologia e sociedade. Eles podem ser usados para a promoção de discussões interessantes em sala de aula, ainda que, em alguns casos, falte apoio suficiente para isso. Apesar de o Manual do Professor oferecer orientações para a abordagem de alguns assuntos, de um modo geral, professora e professor não encontrarão nele um apoio substancial, nem textos complementares para sua formação. Há outros pontos, no entanto, em que 0 manual contribui bastante para a prática pedagógica, como é 0 caso do grande número de propostas de atividades adicionais interessantes, de grande valor pedagógico e de fácil execução. Por fim, esta é uma obra bem cuidada em seus aspectos gráficos, oferecendo ao professor um repertório de boas ilustrações e um texto com poucos problemas de revisão, o que, certamente, ajudará em sua prática pedagógica.

Legenda: CL - códigos e linguagens; CH - ciências humanas; MCN - matemática e ciências da natureza 